\title{
O processo de afirmação da identidade negra em $O$ Black Power de Akin de Kiusam de Oliveira e ilustração de Rodrigo Andrade
}

\author{
Leandro Passos ${ }^{\mathrm{i}}$ \\ Luana Passos ${ }^{\text {ii }}$
}

\begin{abstract}
RESUMO
A concepção do livro voltado para crianças e jovens não parte apenas de um texto já finalizado, mas de um diálogo em que texto, ilustração e contexto sociocultural têm importância determinante. Neste artigo, encontra-se a análise do modo como a palavra literária e a ilustração constroem, na obra O Black Power de Akin, de Kiusam de Oliveira, ilustrada por Rodrigo Andrade, o processo de afirmação da identidade negra da personagem protagonista. Para tanto, serão utilizados os estudos de Gomes (2006), de Munanga (2006), de Duarte (2008), de Pereira (2016), de Debus (2017) e de Cabral (2019). Outros pesquisadores também serão utilizados neste artigo.
\end{abstract}

Palavras-chave: Identidade negra; Ilustração; Linguagem literária; Literatura para crianças e jovens; Poética.

\footnotetext{
${ }^{i}$ Possuo graduação em Letras (2004) pela UNESP - Campus de São José do Rio Preto (IBILCE), Mestrado em Estudos Literários (2008) pela UNESP - Campus de Araraquara (FCL-Ar), e Doutorado em Letras (2012) pela UNESP - Campus de São José do Rio Preto (IBILCE). Sou Professor do Ensino Básico Técnico e Tecnológico de Língua Portuguesa do Instituto Federal de Educação, Ciência e Tecnologia de Mato Grosso do Sul - IFMS Campus Três Lagoas, cidade em que moro. Possuo contos publicados no Cadernos Negros 40 (2017). Pós Doutor (2018-2020) com o tema: mitos bantos e iorubás na obra da escritora Conceição Evaristo.

https://orcid.org/0000-0002-4676-3666 | leandro.passos@ifms.edu.br

ii Graduação em Pedagogia pela UNESP/IBILCE; Mestre em Estudos Linguísticos, linha de pesquisa "Oralidade e Letramento" com pesquisa voltada para a aquisição da linguagem escrita de alunos da Educação de Jovens e Adultos. Doutoranda em Letras na linha de pesquisa História, Literatura e Cultura, com a temática da literatura para crianças e jovens de matriz africana pela UNESP/IBILCE. Atualmente, pela Secretaria Municipal de Educação de São José do Rio Preto, integra a equipe de formação de professores do Ciclo I do Ensino Fundamental. De 2015 a 2017 sou eleita vice-presidente e posteriormente presidente interina do Conselho Afro de Rio Preto. Sou integrante do grupo de Pesquisa Gênero e Raça (UNESP/IBILCE) e somada a essa pesquisa, junto aos estudos sobre a literatura de matriz africana e sobre as Africanidades, desenvolvo cursos de formação de educadores e professores na luta contra o racismo dentro e fora das instituições de ensino e na implementação de atividades didáticas e pedagógicas na perspectiva da Lei 10.639/03. Possui poemas e contos publicados nos Cadernos Negros volumes 41 e 42, este último volume "Cadernos Negros - contos afro-brasileiros" sendo indicado ao Prêmio Jabuti de 2020. | passosluz19@gmail.com
} 


\begin{abstract}
The creation of books aimed at children and young people does not only include a finished text, but a dialogue in which text, illustration and sociocultural context are crucially important. In this article, we analyze how literary language and illustration create the process of affirmation of black identity by the protagonist in $O$ Black Power de Akin, a work written by Kiusam de Oliveira and illustrated by Rodrigo Andrade. To this end, the studies of Gomes (2006), Munanga (2006), Duarte (2008), Pereira (2016), Debus (2017) and Cabral (2019) will be explored. Other researchers will also be addressed in this article.
\end{abstract}

Keywords: Black identity; Illustration; Literary Language; Children and Young Adult Literature; Poetics.

\title{
INTRODUÇÃO
}

A Literatura voltada para crianças e jovens geralmente vale-se da desautomatização da linguagem comum e da imagem para atrair não apenas leitores da infância e da juventude, mas também o público adulto.

Na obra $O$ Black Power de Akin (2020), escrita por Kiusam de Oliveira e ilustrada por Rogério Andrade, tais predicados estão presentes e atrelados aos símbolos e aos valores da cultura africana e afro-brasileira tanto na palavra como na imagem da ilustração. Vale destacar que a obra recentemente foi selecionada pela Secretaria Municipal de Educação de São Paulo a partir do resultado do edital de compra de livros para o "Projeto Minha Biblioteca 2020", o qual distribuiu exemplares aos alunos da rede municipal de ensino da capital paulista. A obra está contemplada na Categoria 4: Ciclo Interdisciplinar.

A narrativa relata o drama de Akin, protagonista que ainda não possui a identidade negra resolvida, principalmente no que diz respeito ao cabelo crespo, comumente chamado em práticas racistas e preconceituosas de "cabelo ruim" e "cabelo duro".

Neste artigo, as discussões giram em torno do processo de afirmação da identidade negra de Akin e o modo como a linguagem literária e a ilustração estruturam este percurso. Dada a natureza do objetivo, tornam-se necessários apontamentos sobre a especificidade da Literatura de autoria negra, os símbolos e os valores da cultura 
africana e afro-brasileira, bem como os da área da Educação, visto que Akin sofre constrangimentos e racismo no espaço escolar.

Os principais referenciais teóricos utilizados para as reflexões aqui propostas estão ligados aos seguintes campos: (1) de Literatura negra no Brasil; (2) das relações étnico-raciais; e, (3) da Educação e das práticas racistas e preconceituosas na instituição escolar.

\section{LITERATURA DE AUTORIA NEGRA: AS CRIANÇAS E OS JOVENS}

A Literatura de autoria negra no Brasil geralmente gira em torno de temas que retomam a cultura africana e afro-brasileira, bem como o preconceito, o racismo, as desigualdades étnico-raciais, as de gênero e de classe social, tendo em vista o processo de escravização pela qual o negro africano foi submetido em terras brasileiras. Embora nem sempre escritores negros tematizem estes conteúdos, grande parte desta produção literária procura trazê-los à tona a fim de problematizar tais questões.

Segundo Duarte, trata-se de "vozes negras saídas do silêncio, bem como sua transformação, desde os lamentos e sussurros, aos gritos vibrantes" (2008, p. 7). O silenciamento de vozes, atrelado ao ocultamento e a demonização da cultura africana e afro-brasileira em nossa sociedade, então, são repensados e escritos por meio da palavra literária para que negros e não negros entrem em contato com um repertório cultural outrora ocultado, mas com uma perspectiva afirmativa.

Almeida e Kirchof (2018), por sua vez, ressaltam que a Literatura de autoria negra atual imprime um "novo gênero" às letras brasileiras, por ter se revelado não somente como um campo muito profícuo de experimentação e de inventividade poética, mas também como um importante lugar de denúncia e de resistência para os negros brasileiros na atualidade.

Alves explica o termo Literatura negra, que teve seu uso defendido pela primeira vez na coletânea da Quilombhoje Cadernos Negros (1978). A expressão, além de consagrar a escrita feita por negros e negras, também propiciou o destaque de textos, de atos e de atitudes literárias no universo da poética negra brasileira já naquela época. A produção literária brasileira, tendo como modelo estético e cultural branco, negava uma 
subjetividade do povo negro, transformando-o em mero personagem secundário ou em espectador de ações alheias, o que pode ser percebido pelos estudos de Dalcastagnè (2008) sobre o perfil do escritor brasileiro. A ideia, portanto, era resistir a essa negação e opor-se aos enquadramentos estéticos que seguiam padrões exclusivamente eurocêntricos, portanto hegemônicos, delineados na história da escravidão, pontua Alves (2002).

A este respeito, Almeida e Kirchof observam que "essas atitudes e iniciativas dos intelectuais ligados aos Cadernos Negros contribuíram para a chamada ‘desconstrução' da tradição literária - compreendida como masculina, branca e cristã” (2018, p. 57). Esta observação é importante para as análises do texto e da imagem, pois a ancestralidade é narrada e ilustrada por meio de símbolos africanos e afro-brasileiros. Hoje, 43 anos após a primeira publicação, os Cadernos representam o mais significativo veículo da Literatura negra produzida no Brasil, destacam os autores, uma vez que cumprem com o papel de denúncia, de protesto e, sobretudo, de divulgação de vozes negras silenciadas pelo cânone brasileiro. Desta forma, a partir deste movimento, renascia uma "nova ideia de liberdade" veiculada pela Literatura negra brasileira por meio de um conjunto de propostas, de significados, de símbolos, de padrões estéticos particulares e de visões de mundo de cosmovisão africana e afro-brasileira (ALMEIRA; KIRCHOF, 2018).

Por fim, tendo em vista esta particularidade da Literatura de autoria negra no Brasil, Duarte (2008) delimita tal produção a partir de cinco eixos ligados às obras: a temática, a autoria, o ponto de vista, a linguagem e o leitor, pois, como apontado, a Literatura negra produziu-se, articulou-se e transformou-se no curso da história do país, não surgindo de um momento para outro, além de não ter obtido autonomia e reconhecimento desde os seus primeiros registros.

Na obra $O$ Black Power de Akin da escritora Kiusam de Oliveira, e ilustração de Rodrigo Andrade, o tema gira em torno do cabelo crespo da personagem protagonista atrelado ao racismo, ao preconceito e à ancestralidade africana e afro-brasileira, principalmente no espaço escolar. Ainda conforme Duarte (2008), a temática negra compreende as tradições culturais ou religiosas transplantadas para o Brasil, muitas vezes, marcada pela oralidade; outra vertente dessa diversidade temática é vista na história contemporânea, em que são descritos os dramas vividos na modernidade 
brasileira; há também outros que retomam a história do povo negro na diáspora brasileira, trazendo a denúncia da escravidão e de suas consequências, assim como a glorificação de heróis, muitas vezes desconhecidos, que lutaram contra o cativeiro. Ao trazer o drama de Akin na escola e a ancestralidade por meio do avô, Seu Dito Pereira, a obra também lança mão de recursos linguísticos poéticos e de imagens simbólicas da religiosidade a fim de construir e fortalecer a identidade negra da personagem ainda fragilizado.

No que diz respeito à autoria, não há dúvidas de que tanto a escritora quanto o ilustrador sejam negros e, até mesmo, são "ilustrados assim" nas páginas finais da obra (figuras 1 e 1.1), recurso que reafirma Cortazzo, ao observar que a Literatura negra tem, como principal alicerce, "uma política corporal que se desenvolve como uma estética identitária" (2011, p. 6), e, desta forma, a teorização não deve separar o corpo, a identidade e a escrita.

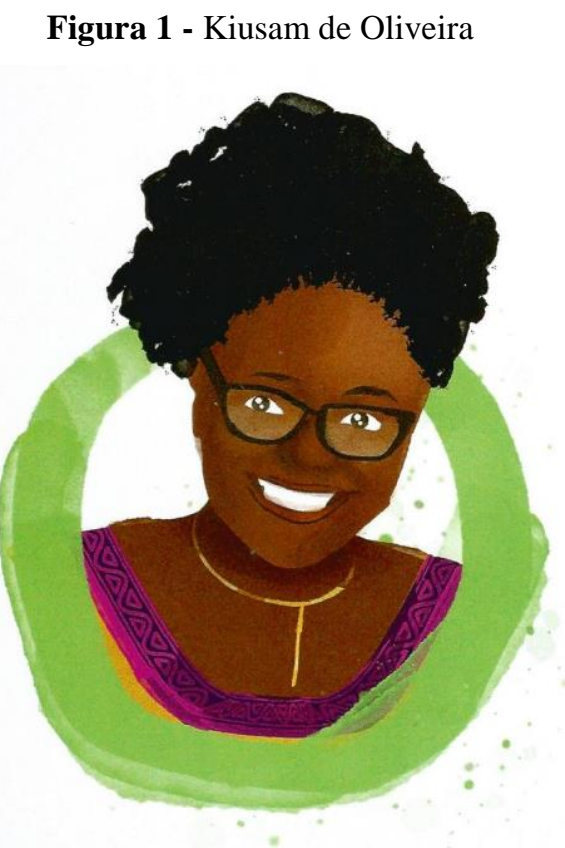

Fonte: Rodrigo Andrade, OLIVEIRA (2020, p. 38). 
Figura 1.1 - Rodrigo Andrade

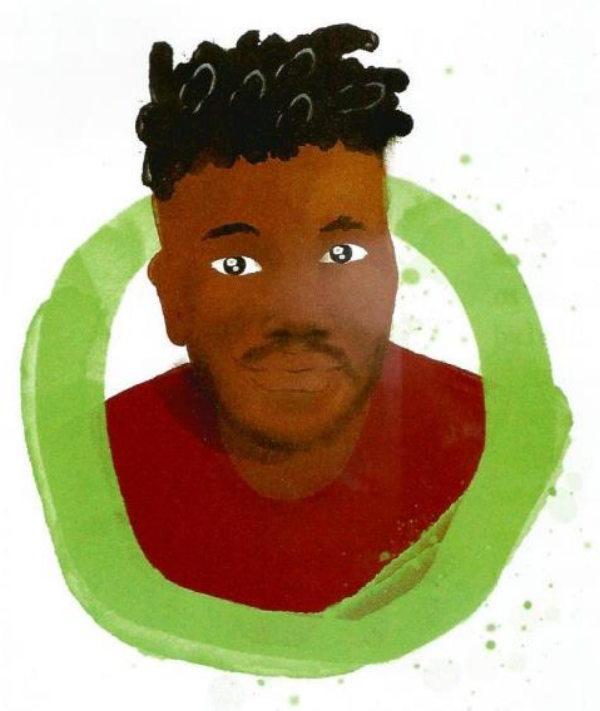

Fonte: Rodrigo Andrade, OLIVEIRA (2020, p. 39).

Próximo à autoria da escrita literária de Oliveira e da ilustração de Andrade, o ponto de vista se faz negro, pois "tão relevante ou mais que a explicação da origem autoral é o lugar a partir do qual o autor expressa sua visão de mundo" (DUARTE, 2008 , p. 6). Sabe-se que o conteúdo narrado e ilustrado faz parte da realidade do povo negro e, principalmente, é relatado a partir desta perspectiva (figuras 2 e 2.2).

Figura 2 e 2.2 - Seu Dito Pereira (avô) e os netos

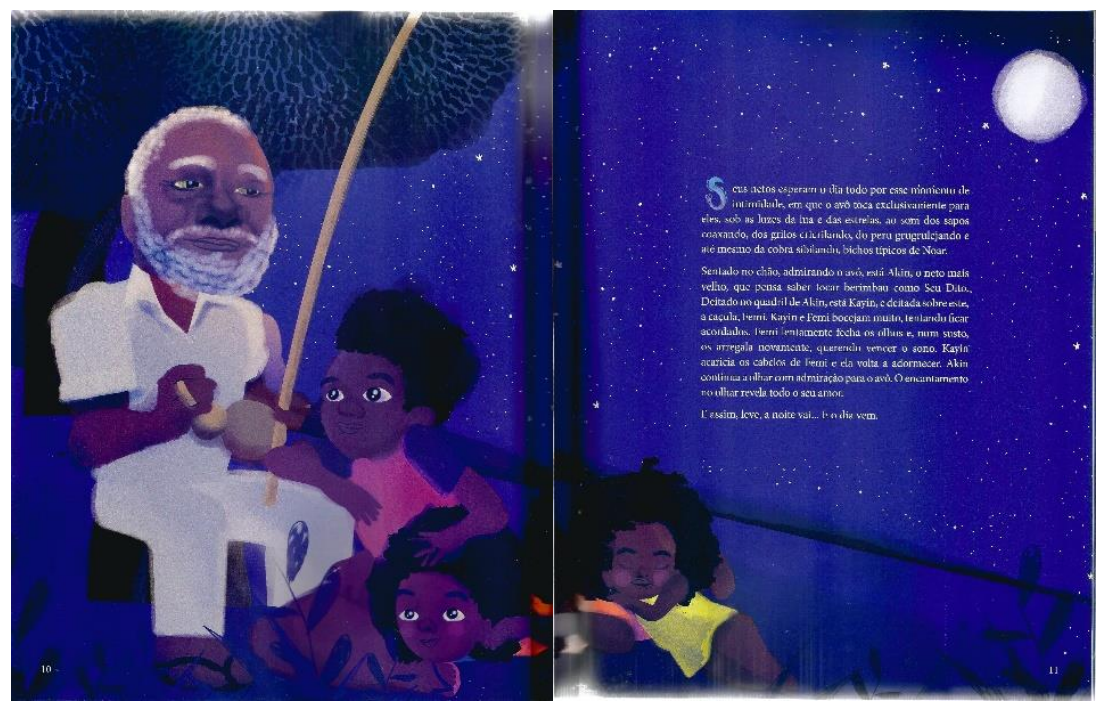

Fonte: Rodrigo Andrade, OLIVEIRA (2020, p. 10-11). 
Sobre a linguagem, a Literatura negra almeja a configuração de uma "nova ordem simbólica" (BERND, 1988), dentre os principais recursos presentes são a acolhida de ritmos negros (do samba, do batuque, do candomblé etc.), de sonoridades de origem africana, de um vocabulário rico e resgatado da oralidade, principalmente no gênero lírico. Além disso, há escolhas poéticas com especificidades da linguagem e, no caso da obra em análise, visuais, num esforço para ultrapassar " [...] o aprisionamento linguístico" - imposto pela colonização - e elaborar "novos arranjos discursivos em que identidades mutantes podem ser vislumbradas nos matizes de cores e nos gestos ressignificados" (FONSECA, 2002, p. 204-205).

Logo, como pontua o autor, tal procedimento ultrapassa a norma literária vigente e, por vezes excludente, e a linguagem, para a literatura negra, torna-se "o ponto de distanciamento entre o passado obsedante e o futuro em construção". (FONSECA, 2002, p. 204-205). Na obra, por exemplo, a palavra "garfo" readquire e se reafirma como elemento simbólico da cultura afro não por somente valorizar o pente usado por negros para pentear o cabelo crespo e cacheado, mas também por, justamente, ser retomado na situação de fragilidade identitária da personagem Akin por conta de seu cabelo crespo (figura 3).

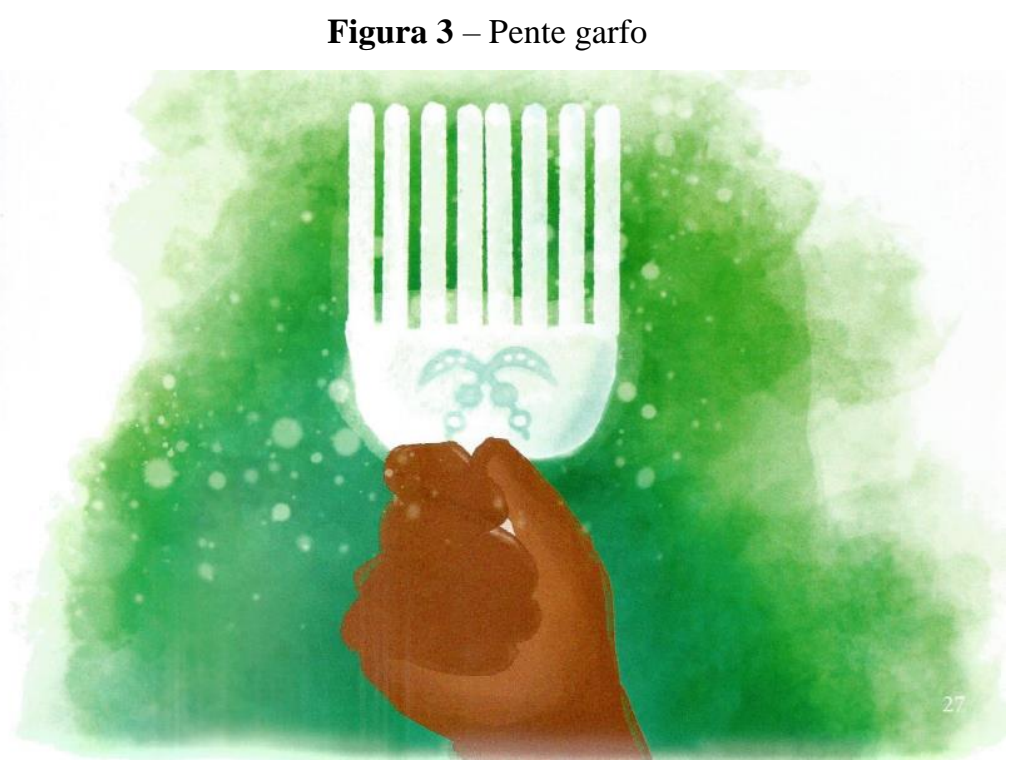

Fonte: Rodrigo Andrade, OLIVEIRA (2020, p. 27). 
Enquanto pergunta, Akin descobre um fundo falso na pasta e retira de lá o tesoura guardado pelo avô e o ergue, como quem ostenta um troféu.

- Isso mesmo, Akin: um garfo de marfim, feito do dente de um elefante encontrado morto muito tempo atrás. O avô, do bisavô, do trisavô, do tataravô do seu tataravô o encontrou e fez esse artefato com as próprias mãos. Esse garfo é o pente usado pele nobreza africana e está em nossa família há alguns séculos.

Femi e Kayin olhavam surpresos para o avô e para o garfo, encantados com aquela relíquia africana.

Seu Dito Pereira pegou o garfo das mãos de Akin e começou a pentear os cabelos crespos do neto. (OLIVEIRA, 2020, p. 27)

Embora haja outros elementos da linguagem escrita e visual que serão aqui analisados, neste fragmento supracitado, há a "nova ordem simbólica” (BERND, 1988) e o futuro em construção - identidade negra de Akin - operados pelo pente-garfo de marfim dos ancestrais de Akin.

O último eixo sugerido por Duarte (2008, p. 20) é o público-leitor afrodescendente. Segundo o autor, a formação de um público específico, "marcado pela diferença cultural e pelo anseio de afirmação identitária", compõe o lado mais ousado e utópico do projeto literário negro, uma vez que se trata de intervir num processo sobremaneira complexo e num campo adverso, em que duas principais metas se impõem: uma, a de fazer com que o leitor entre contato com a literatura afro-brasileira e, particularmente, com os novos modelos identitários propostos para a população afrodescendente; e a outra, o desafio de dialogar com o leitor e suas expectativas, muitas vezes já fragilizadas pelo racismo e pelo preconceito ocorridos desde a tenra idade.

Duarte (2008) salienta que, excluído do projeto que norteou a Literatura brasileira canônica, os leitores afrodescendentes surgem, neste momento como fatores de intencionalidades próprios da Literatura negra. Portanto é importante destacar ainda que, para Duarte, nenhum desses eixos isolados garante o pertencimento de uma obra ao campo da Literatura Negra, mas a interação entre tais elementos é o elemento significativo: "isoladamente, tanto o tema, como a linguagem e, mesmo, a autoria, o ponto de vista, e até o direcionamento recepcional são insuficientes" (2008, p. 12). Logo, tanto o público-leitor afrodescendente quanto o não negro precisam entrar em contato com tais obras, o que exige outro olhar e outras posturas no ato leitor tendo em vista a trajetória literária ao qual foram e estão submetidos.

Cabem aqui as observações de Oliveira (2019), ao tratar da Pedagogia da Ancestralidade, quando explica que se trata 
[...] antes de tudo, um posicionamento político contrário ao que se estabeleceu no país como uma lógica incontestável, direcionada ao branco, considerado a norma, enquanto o não-branco é o desvio. É uma pedagogia que se opõe ao colonialismo e à colonialidade, que continuam reafirmando a desumanidade de negros e indígenas.

Ela se opõe à hegemonia epistemológica eurocentrada, propondo uma forma de ser-pesquisar-conhecer-pensar-juntar-articular-agir que reconheça o continente africano como o berço da humanidade e se dá a partir da criação ou recriação de laços e formas afeto-coletivas de acolher-ouvir-aprenderfalar-trocar-compartilhar, protagonizada não só pelas/os mais velhas/os, mas também pelas crianças e jovens. (OLIVEIRA, 2019)

A Pedagogia da Ancestralidade proposta por Oliveira está em consonância com o eixo público-leitor afrodescendente de Duarte (2008) ao estabelecer uma ruptura provocada pela decolonialidade: "não se trata mais de falar pelo corpo, mas proporcionar situações para que o próprio corpo fale por si, alimentado pela cultura vivida na e pela carne" (OLIVEIRA, 2019). Na perspectiva da autora, esse corpotemplo, que se (re)significa na e para a resistência, com o propósito de se tornar um corpo-templo-resistência - já que resistir às atrocidades também é sagrado -, culmina por estar conectado com a realidade vivida na coletividade, em seu entorno e, assim, é um corpo capaz de sobreviver às intempéries sociais. O público-leitor, desta forma, deve estar atento às mudanças marcadas pela Literatura negra, a qual problematiza não apenas conteúdos histórico-culturais, mas também de gênero e de raça/etnia.

Para Oliveira (2019), há a necessidade de a criança negra saber não somente que há um exército ancestral com as paramentas de combate para lutar por ela, como também que há um exército negro e feminino na contemporaneidade, espalhado por todo o Brasil, que jamais soltará a sua mão e que só deseja que a criança negra se ame e, deste modo, se cure. Já Silva, ao responder uma pergunta ao Portal Literafro, "parafraseando a pesquisadora Dalcastagnè (2014), para que o Brasil precisa de escritora(e)s negros?", deixa claro que é "para humanizar o Brasil e a literatura. Para integrar estética e ética. Para produzir polifonia no olhar. Para polinizar oralituras mil. Para fazer com esse país se orgulhe de se ver no espelho africano-diaspórico" (SILVA, 2014, p. 4).

Por fim, a pesquisadora Debus traz contribuições pertinentes ao dizer que a literatura para crianças e jovens "não é a prima pobre de uma literatura rica, por isso não tem sustentação desqualificar uma em detrimento da outra" (2017, p. 36). Segundo 
Debus, as reflexões acerca dessa produção têm ganhado forças contemporaneamente e são muitos os vieses de pesquisas que tentam abarcar a sua confecção, circulação e consumo. Além disso, Debus observa, mesmo assim, que o livro literário para a infância e juventude possui, sim, suas particularidades: tamanho e formato, paratextos que constituem a capa, as guardas e a contracapa; tipo e tamanho de letra; tipo, qualidade e textura do papel; diálogo entre a mancha textual e ilustração, entre outros.

No que diz respeito à ilustração, cujo papel é intrínseco nas publicações, também é lida como narrativa, fato que ganha proporções maiores quando se traz para a cena os livros com imagens e de imagens. A relação entre o signo icônico e o verbal nesse tipo de produção é tão estreita que tem acompanhado os critérios de escolhas dos livros, como pode ser visto em trabalhos recentes sobre a avaliação dos títulos que compõem os acervos literários das escolas públicas para as séries iniciais do ensino fundamental, como trabalho desenvolvido pelos avaliadores dos livros selecionados para comporem o Programa Nacional Biblioteca da Escola - PNBE - (DEBUS, 2017).

Desta forma, a obra direcionada para crianças e jovens é composta, majoritariamente, por texto (palavra) e imagem (ilustração) que, juntas, a estruturam como um todo. Cabral observa que:

\footnotetext{
No século XX, em que houve a pretensão de libertar a literatura infantojuvenil do vínculo didático e transformá-la em arte amadurecida, e assim inúmeras novas possibilidades surgiram, começou-se a refletir sobre o desenvolvimento do objeto-livro para crianças e jovens como sobrevivência em meio a vasta produção de bens culturais voltados à infância - desenhos animados, propagandas, brinquedos, jogos eletrônicos, filmes, etc. A literatura infantil passa então de um desafio para a criança pós-moderna para aliada. (2019, p. 122)
}

Percebe-se a importância da ilustração nos textos voltados para crianças e jovens e o desafio dos educadores em fazer a mediação durante a leitura quando o texto visual possui símbolos africanos e afro-brasileiros como os presentes no livro em análise.

Neste artigo, será analisado de que modo a palavra e a imagem constroem, pelo viés do poético, o processo de afirmação da identidade negra de Akin. 


\section{O BLACK POWER DE AKIN}

A obra em análise destaca a questão familiar e ancestral como um dos centros potentes da narrativa que oferece apoio à personagem Akin para a superação de conflitos no que diz respeito ao cabelo crespo.

\footnotetext{
Sentado num toco de árvore, Seu Dito Pereira, com seu berimbau, canta uma linda ladainha. Ele, um senhor altivo, com os olhos vivos e o olhar penetrante aos 78 anos, é o responsável pelos seus três netos: Femi, caçula de 4 anos, Kayin de 6 anos e Akin de 12. (OLIVEIRA, 2020, p. 8)
}

As primeiras linhas da narrativa já trazem a ancestralidade marcada pelo avô das crianças, pelo instrumento berimbau e, também, pelo cantar da "linda ladainha". O nome próprio, Dito, chama a atenção não apenas por ser o particípio do verbo "dizer", mas também por ser o nome bastante comum das entidades da religião umbamba de matriz africana e afro-brasileira, os Pretos Velhos: o dizer personifica-se na figura do avô ancestral. Tal articulação da palavra literária retoma a questão dos temas da Literatura Negra já apontada por Duarte (2008).

Amorim e Machado explicam que o instrumento berimbau é bastante significativo na e para a capoeira, pois "comanda todo o jogo e dita o ritmo que os jogadores desenvolverão na roda e, por isso, tornou-se comum dizer que o berimbau é o mestre da roda, é quem identifica quais os movimentos que serão realizados" (2018, p. 4). No decorrer da narrativa, percebe-se que Seu Dito torna-se "berimbau" para o processo de afirmação da identidade negra de Akin, tendo em vista que, assim como o instrumento, a personagem dá "ritmo" ao neto, bem como à trama narrativa. Vale destacar que a ilustração (figura 4) possui tons escuros por se tratar da noite: "A lua alta no céu estrelado é coisa linda de se ver na cidadezinha de Noar" (OLIVEIRA, 2020, p. $8)$. 
Figura 4 - Céu estrelado

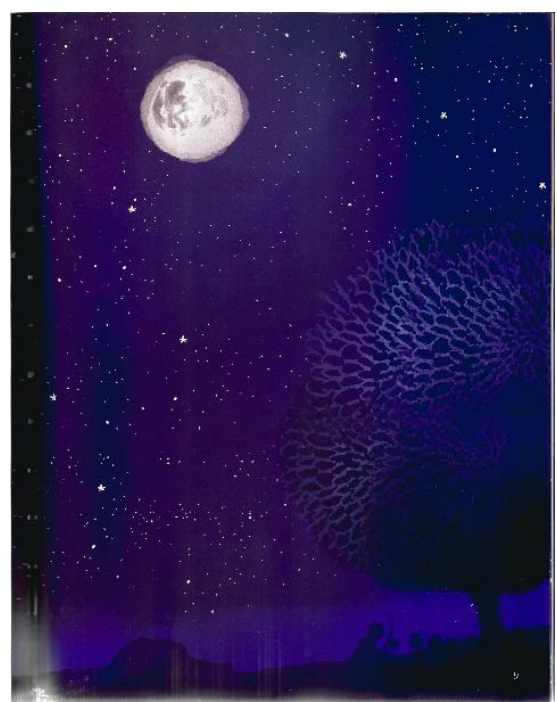

Fonte: Rodrigo Andrade, OLIVEIRA (2020, p. 9).

Nas páginas seguintes da obra, 10 e 11, a narrativa visual segue com as cores escuras como a noite, as quais se contrastam com a Lua, a roupa, os cabelos e a barba brancas de Seu Dito; as crianças deitadas e escoradas sobre o avô sentado num banquinho usam roupas coloridas (Akin lilás, Kayin laranja e Femi amarelo). O narrador relata que as crianças esperam o dia todo por aquele momento de intimidade:

Kayin e Fami bocejam muito, tentando ficar acordados. Femi lentamente fecha os olhos e, num susto, os arregala novamente, querendo vencer o sono. Kayin acaricia os cabelos de Femi e ela volta a adormecer. Akin continua a olhar com admiração para o avô. O encantamento no olhar revela o seu amor. E assim, leve, a noite vai... E o dia vem. (OLIVEIRA, 2020, p. 11)

Este ambiente harmônico realiza-se no espaço familiar da família de Akin, mas é alterado, na página que se segue (12) com o nascer do dia: Akin, ao arrumar o cabelo crespo, "[...] faz cara de quem não gostou e, molhando as mãos, aperta, esfrega e puxa os fios para trás" (OLIVEIRA, 2020, p. 12). O protagonista vê os irmãos brincando e, ao contrário dele, admiram os próprios cabelos; a personagem quer o "cabelo assentado, grudado na cabeça" e, por isso, apanha o boné. Coerente com a manhã e com o cantar do galo, as cores da ilustração são claras e mostram Akin entristecido em frente ao espelho. O leitor vê o reflexo da personagem no espelho e o fragmento de seu corpo no canto da página, o que sugere a fragmentação do todo da criança e, consequentemente, da identidade tênue e fragilizada. A personagem mente para o avô ao responder que o 
uso do boné é porque está na moda e que todos os meninos usam. Seu Dito, desta forma, concorda e responde: "Ah, bom, sendo assim... Vá, meu neto, vovô te ama!" (OLIVEIRA, 2020, p. 13).

No mesmo tom claro alaranjado da ilustração (páginas 13 e 14), o conflito permanece e, na Escola Estadual Zacimba Gaba, Akin vê os colegas de sala, todos, sem boné. No intervalo, as personagens Paulo e Marcos, durante a brincadeira de pega-pega, chamam Akin de "Pelé", atitude que o deixa constrangido, pois responde: "Me solta! Meu nome é Akin; não quero mais brincar disso!" (OLIVEIRA, 2020, p. 14). A palavra literária organiza-se, nestes fragmentos, de modo singular; ao mesmo tempo que a Literatura se faz negra (DUARTE, 2008), ao resgatar a história, sinalizada pelo nome da Escola, e o conflito narrativo se insere.

Comum em práticas racistas e preconceituosas, "desnomear" pessoas negras de todas as idades é comum dentro e fora dos espaços escolares. Akin tem nome próprio. A linguagem "kiusamiana" corrobora no construto identitário a partir do nome, o qual é importante para a construção e para o fortalecimento da identidade individual. Akin: nome próprio africano significa homem valente, guerreiro, herói. Nomear, portanto, a criança pelo seu nome próprio, sem estereótipos e sem apelidos pejorativos, é empoderamento. Quando as crianças negras carregam e são identificadas por um nome ancestral, um nome do tronco africano, já que Akin é um nome iorubá (Nigéria), é construída, também, a sua identidade individual, pois o nome retém memórias e ancestralidades. Assim como o nome funciona como marca identitária, as escariações, as pinturas no corpo, o modo de se vestir e os modelos de penteados também são identidades individuais.

Os nomes próprios em yorubá, orùko, "são formados por diversas palavras, vindo a compor um nome relacionado com fatos ou divindades, entre outras coisas, tornando-os bastante significativos" (BENISTE, 2014, p. 594). Quando se recebe o orùko aqui no Brasil, esse nome passa a diferenciar o nascido de suas irmãs, de seus irmãos, de seus pais e de seus avós. O nome representa, assim, a identidade individual e familiar de uma pessoa e marca a existência e a pertença no mundo.

No que diz respeito ao nome da Escola de Akin, Gonçalves (2017) elenca 17 mulheres negras que fizeram parte de quilombos brasileiros e se mostraram fundamentais para a comunidade negra. A autora esclarece que as histórias são relatadas 
nos cordéis de Jarid Arraes e do Mural Memória das Mulheres Negras, acervo do Instituto Políticas Alternativas para o Cone Sul, Rio de Janeiro. Jacimba Gaba era Princesa angolana e acabou no Espírito Santo no Brasil; idealizou uma revolta das pessoas escravizadas contra a casa grande e liderou um quilombo onde foi rainha. Comandou, durante anos, ataques aos navios, surgindo, no meio da noite, em canos das cidades para resgatar os negros escravizados.

Voltando à narrativa, após o clima tenso pelo tratamento de mal gosto, nova brincadeira - pique-esconde - é sugerida, e nova ofensa proferida: “- Achei! Achei o 'Buiú'!, - Parem com isso. O que estão fazendo não é certo. Vocês sabem o meu nome! - retrucou Akin" (OLIVEIRA, 2020, p. 15). A personagem se afasta dos demais alunos, isola-se do outro lado do pátio e pensa o porquê daquele tratamento que reforça a cor da pele e sente vontade de desaparecer: "Aquela manhã estava bem difícil para Akin..." (OLIVEIRA, 2020, p. 15). Embora haja o clima de tensão ocorrido no espaço escolar, o personagem obtém paz sozinho, o que é marcado pelo tom azul-escuro da página, que inicia a obra em análise durante à noite.

Mesmo percebendo o constrangimento de Akin, Paulo e Marcos sugerem outra brincadeira - polícia e ladrão - e, mais uma vez, novas ofensas são ditas:

\footnotetext{
Akin, que por um instante se esqueceu da mágoa que sentia, pulou e disse:

- Eu quero ser a polícia!

Marcos comentou:

- Polícia? Onde já se viu alguém de sua cor brincar de ser a polícia? Não! Nós vamos ser a polícia e você será o ladrão, que vai roubar as galinhas do Seu Dito Pereira.

Os amigos gargalham de se jogar no chão. (OLIVEIRA, 2020, p. 18)
}

Os personagens Paulo e Marcos reproduzem o racismo estrutural bastante presente na sociedade brasileira, postura que remete aos estudos de Fazzi (2004) e de Almeida (2020) acerca do preconceito racial na infância e na sociedade como um todo. Para a autora, entender como crianças, nas relações entre si, constroem um universo preconceituoso é de fundamental importância para que se compreenda a ordem racial desigual existente no Brasil, como as presentes nas ações das personagens Paulo e Marcos, por exemplo.

A partir de Porter (1973), Fazzi (2004) aponta oito mecanismos de aquisição de atitudes raciais, dentre os quais destacam-se, para a análise da narrativa $O$ Black Power 
de Akin: (1) família, por meio de processos de identificação entre filhos, pais e responsáveis, e da existência de overheard conversations - conversas entre adultos realizadas na presença de crianças; (3) comentários de pares - grupo de brincadeiras ou da escola; (5) associações culturais e simbólicas de cores - conotação positiva para as palavras branco ou claro, e negativa para preto, negro e escuro; (6) material de leitura infantil estereotipado - livro didático e literário; (7) meios de comunicação de massa por meio, principalmente, de exposição direta ou dos comentários dos adultos sobre os assuntos veiculados pela televisão, por exemplo; (8) a própria observação feita pela criança da ocupação racial de papéis sociais (FAZZI, 2004).

Almeida aponta que o racismo é uma decorrência da própria estrutura social, ou seja, "do modo 'normal' com que se constituem as relações políticas, econômicas, jurídicas e até familiares, não sendo uma patologia social e nem um desarranjo institucional" (2020, p. 50). De acordo com o filósofo, determinados comportamentos individuais e institucionais, como os de Paulo e Marcos no espaço escolar, são derivados de uma sociedade racista e, muitas vezes, legados pela tradição.

Paulo e Marcos exteriorizam o que, provavelmente, ouviram no espaço familiar de suas casas, em que os pares, durante as conversas, expõem o racismo e o preconceito racial; possivelmente, leram em livros didáticos ou literários reproduções negativas da cultura afro-brasileira. Além disso, as personagens, que agridem Akin, verbalmente, associam o negro, a sua cultura e os seus símbolos ao negativo, por não admitirem que o protagonista da obra possa ser policial (positivo), mas sim bandido e ladrão de galinhas (negativo) do próprio avô que o cuida. Não somente "desnomeiam" Akin, chamando-o de "Pelé" e "Buiú", mas também atribuem ao garoto a ingratidão e a desestruturação da família, já que, mesmo por "brincadeira", dizem que ele rouba o Seu Dito, desvalorizando a relação familiar.

\footnotetext{
O sinal tocou, a aula prosseguiu e terminou. Akin voltou para casa quase sem forças para caminhar, numa tristeza infinita. Nem Kayin nem Femi conseguiram tirar um sorriso de seus lábios. À noite, sentado aos pés do avô e seu berimbau, chorou olhando para as Três Marias. Naquela noite, Akin não sentiu o cheiro do pão, do café nem mesmo do bolo de fubá. Foi dormir e sonhou. (OLIVEIRA, 2020, p. 17)
}

Ao sair do espaço escolar e voltar para o espaço ancestral familiar (casa), os tons escuros em azul retomam na obra como positivos, e Akin é inserido, por meio do sonho, 
no mundo ancestral. Vale destacar que os tons brancos e claros, vistos culturalmente como positivos em nossa sociedade, são, no texto visual de Rodrigo Andrade, substituídos pelos escuros, juntamente com a escuridão da noite (figuras 5, 6 e 6.1), muitas vezes vistos como negativos, mas ressignificados positivamente a partir da cultura africana e afro-brasileira.

Munanga (2006), no prefácio de Gomes (2006), destaca que:

Desde a construção da ideologia racista, a cor branca com seus atributos nunca deixou de ser considerada como referencial da beleza humana com base na qual foram projetados os cânones da estética humana. Por uma pressão psicológica visando à manutenção e à reprodução dessa ideologia que, sabe-se, subentende a dominação e a hegemonia 'racial' de um grupo sobre outros, os negros introjetaram e internalizaram a feiura do seu corpo forjada contra eles, enquanto os brancos internalizavam a beleza do seu corpo forjada em seu favor.

Visto desse ângulo, 'nosso' corpo e seus atributos constituem o suporte e a sede material de qualquer processo de construção da identidade. [...] Ora, para libertar-se dessa inferiorização, é preciso reverter a imagem negativa do corpo negro, através de um processo de desconstrução da imagem anterior e reconstrução de uma nova imagem positiva. (MUNANGA, 2006, p. 15)

O escuro e o negro adquirem na ilustração outra conotação da apontada por Munanga (2006). Os estudos de Ford (1999), sobre a semântica e os valores culturais da palavra negro, por sua vez, descrevem outra perspectiva.

Segundo o autor, não se dá a oportunidade de ir além da história da raça, da política, da economia, da sociologia ou da psicologia social, para pensar o porquê de a palavra negro e branco carregarem pesos tão diferentes. Segundo o autor, as raízes e o poder simbólico destas palavras podem ser mais bem compreendidos no contexto mitológico, ainda que a mitologia, dificilmente, esteja presente no discurso moderno sobre raça. Para Ford (1999), a mitologia tem potencial de mostrar o quão ancestral na antiguidade essas questões emergem.

O Avesta, texto sagrado do zoroastrismo, pintou esse conflito em preto-ebranco. $\mathrm{Na}$ época em que se intensificaram os contatos entre a Europa e a África, nos séculos XV e XVI, já estava bem firmada uma mitologia europeia de deificação e de demonismos: os deuses tinham pele branca, os diabos, pele negra, e era dever dos deuses subjugar os diabos. Grande parte da história do Ocidente incorpora essa mitologia simples, mas devastadora, que lança as pessoas de pele branca contra as de pele negra - uma cultura mitológica que nos assola até hoje continua registrada [...] (FORD, 1999, p. 35) 
O pesquisador explica, também, que linguistas rastrearam a palavra negro como cor, na raiz grega melan, da qual deriva a palavra moderna melanina. Melanto, deusa grega é ligada à negrura da terra fértil, mas "esses termos relacionados com a raiz da palavra melan podem derivar ainda de uma palavra egípcia que se escreve $M 3 n w$, que significa simplesmente "Montanha no Oeste" (FORD, 1999, p. 35-36). O autor esclarece que o sol desaparece no oeste, por trás das montanhas a oeste e desliza para a escuridão mítica do mundo debaixo; a viagem do sol para o mundo debaixo é relacionada aos ciclos de morte e renovação da vida: o ciclo diário da consciência humana do mundo iluminado pelo dia para o mundo escuro dos sonhos, de onde retorna outra vez. Ainda conforme Ford (1999), o lançamento de semente ocorre na escuridão fértil da terra, ação que se realiza, simbolicamente, por meio do sonho de Akin que irá reencontrar com os ancestrais africanos:

\section{Figura 5 - Akin sonhando (espaço casa)}

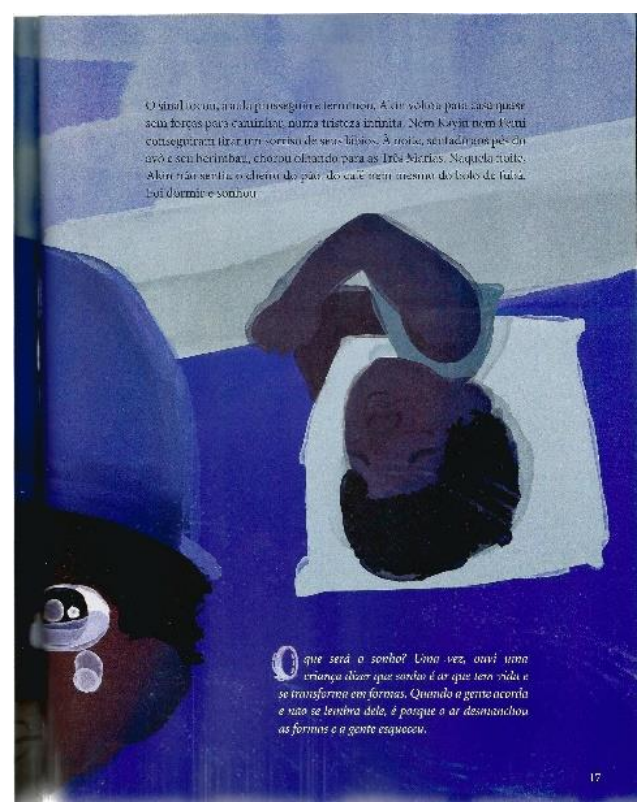

Fonte: Rodrigo Andrade, OLIVEIRA (2020, p. 17). 
Figura 6 e 6.1 - O sonho de Akin com o caçador

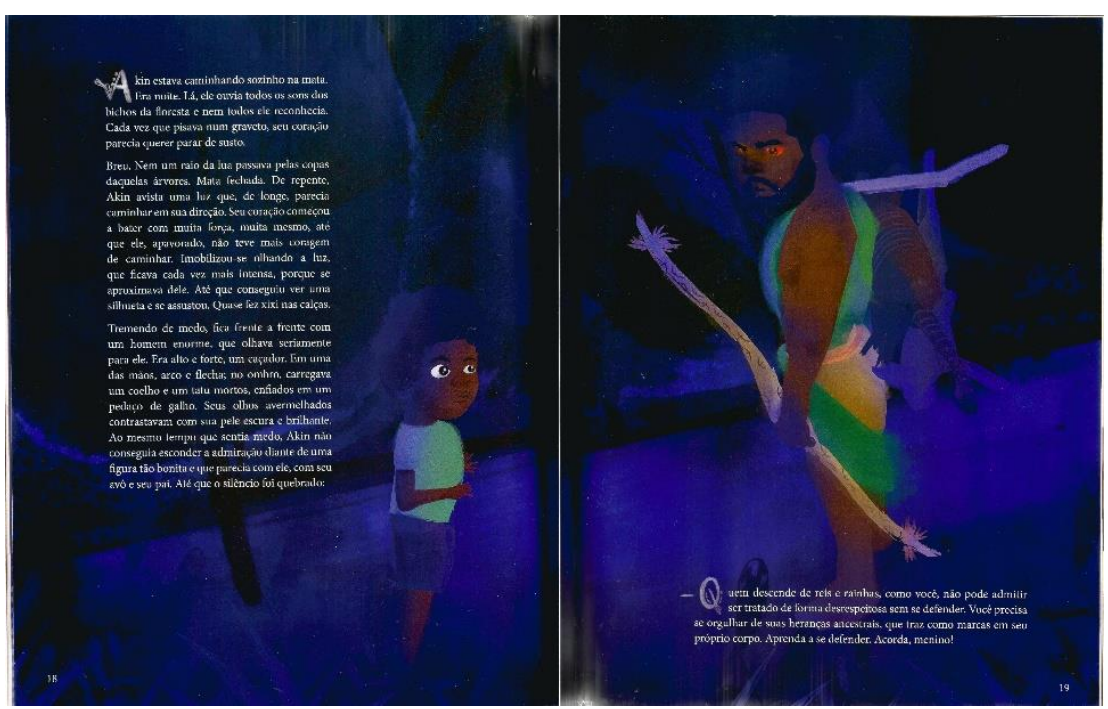

Fonte: Rodrigo Andrade, OLIVEIRA (2020, p. 18-19)

No sonho, Akin caminha sozinho na mata, à noite, no breu; depara-se com um homem negro enorme que o olha seriamente:

Era alto e forte, um caçador. Em uma das mãos, arco e flecha; no ombro, carregava um coelho e um tatu mortos, enfiados em um pedaço de galho. Seus olhos avermelhados contrastavam com sua pele escura e brilhante. Ao mesmo tempo que sentia medo, Akin não conseguia esconder a admiração diante de uma figura tão bonita e que parecia com ele, com seu avô e seu pai. (OLIVEIRA, 2020, p. 18)

Neste ambiente escuro da noite, do breu e das matas, Akin depara-se com o caçador que o orienta, ao dizer que, por ser descendente de reis e rainhas, não pode admitir ser tratado de forma desrespeitosa, se orgulhar das heranças ancestrais presentes em seu próprio corpo: “Acorda, menino" (OLIVEIRA, 2020, p. 19). Como descrito por Duarte (2008), no que diz respeito ao tema, a presença de guerreiros é comum na 
Literatura de autoria negra. Pela descrição narrativa e da ilustração, a personagem do sonho pode ser associada às divindades iorubá (Oxossi) e banto (Mutalambô): caçadores guerreiros da fertilidade.

Ford (1999) salienta que o panteão iorubá é significativo não só por ocupar uma posição central desta cultura, mas também porque as divindades sobreviveram nas Américas. Há uma abordagem que considera os orixás (Oxossi, por exemplo) personificações de energias-arquétipo que se manifestam na natureza e na vida humana. Já sobre os bantos, o autor ressalta que se encontra uma rica variedade de sagas heroicas na mitologia, contando aventuras nas terras celestiais da divindade e no mundo debaixo dos espíritos, dos mortos, repleta de seres dotados de dons sobrenaturais. Desta forma, por meio do resgate ao mítico ancestral da cultura africana iorubá e banto, Akin inicia o processo de afirmação da identidade negra orientado por Oxossi/Mutalambô.

A ilustração, nas páginas seguintes, readquire as cores brancas e claras, o que na narrativa ainda é negativa para o protagonista. Com o amanhecer do dia e com cantar do galo, no espaço escolar, Akin sofre as agressões de Paulo e Marcos: "O cabelo de Akin é duro e torcido, duro e torcido..." (OLIVEIRA, 2020, p. 20).

Segundo Gomes:

\begin{abstract}
Qualquer processo identitário é conflitivo na medida em que ele serve para me afirmar como um 'eu' diante de um 'outro'. A forma como esse eu 'eu' se constrói está intimamente relacionada a maneira como é visto e nomeado pelo 'outro'. E nem sempre essa imagem social corresponde à minha autoimagem e vice-versa. Por isso, o conflito identitário é coletivo, por mais que se anuncie individual. (2006, p. 20)
\end{abstract}

Conforme a autora, ainda há uma zona de tensão. É dela que emerge e se configura um padrão de beleza corporal real e um ideal. No Brasil, por exemplo, esse padrão ideal é branco, mas o real é negro e o mestiço, caso se leve em consideração os dados do IBGE. O tratamento dado ao cabelo pode ser considerado uma das maneiras de expressar essa tensão, e a consciência ou mesmo o encobrimento desse conflito, vivido na estética do corpo negro, marca a vida e a trajetória de sujeitos, por isso, para o negro, a intervenção, às vezes agressiva, do cabelo e do corpo é mais do que uma questão de vaidade ou tratamento estético; é identitária. (GOMES, 2006).

O protagonista, dado o preconceito dos alunos da escola, foge para casa: 
Lá, foi para o banheiro. Subiu no banquinho e se olhou no espelho, que refletiu uma imagem: era ele, mas branco, cabelo liso, com topete e olhos azuis. Ele se assustou, piscou os olhos e chacoalhou a cabeça. Abriu as pálpebras novamente e continuou a se enxergar branco. Sorriu. (OLIVEIRA, 2020, p. 20)

Além de se enxergar não negro (figura 7), Akin retomou as brincadeiras anteriores na escola e se imaginou o policial na brincadeira, sendo respeitado pelos colegas que, para ele, sorriam, mostrando-lhe respeito. Mas, entristecido, abriu e fechou os olhos e se viu um menino negro. Ao tentar cortar o cabelo com a tesoura, é impedido pelo avô que o abraça, apesar de a resistência inicial do menino.

Figura 7 - Akin no espelho

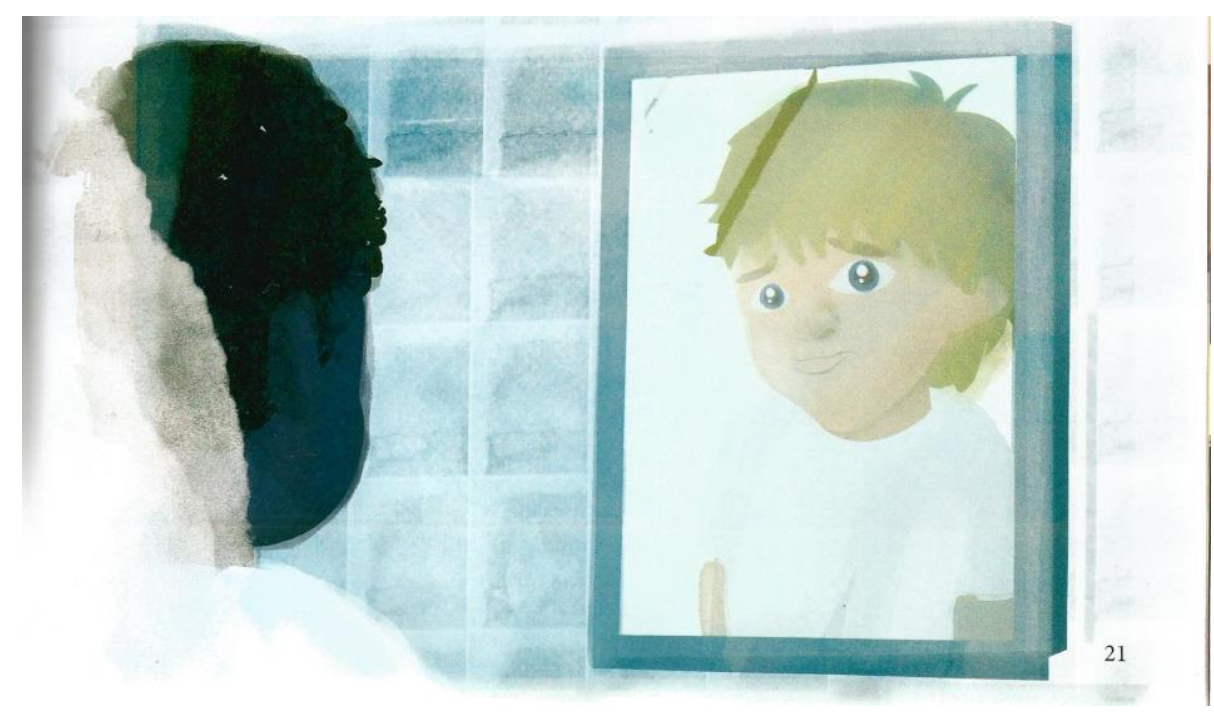

Fonte: Rodrigo Andrade, OLIVEIRA (2020, p. 21).

Seu Dito Pereira segura os ombros do neto, que mantém a cabeça para baixo. Erguendo a cabeça dele e olhando bem no fundo de seus olhos, diz sem nada falar: “"Tenha orgulho de si mesmo'. Então, retira Akin do banheiro e o leva para a sala." (OLIVEIRA, 2020, p. 22). Após conversar com os netos, Akin, Femi e Kayin, o avô pega o berimbau e canta uma ladainha, cujo conteúdo relata o sofrimento e a desvalorização do negro na sociedade, mas alerta-os sobre a luta que se faz necessária para que se alcance a valorização e o respeito. Desta forma, assim como a divindade Oxossi/Mutalambô, Seu Dito orienta e, também, ajuda o neto a se fortalecer e a reagir. 
A partir de então, visto que se inicia o processo de afirmação da identidade negra de Akin, os tons claros e brancos, antes sinalizados com as ações negativas sofridas pelo protagonista, mesclam-se com as ações afirmativas no empoderamento negro (figura 8).

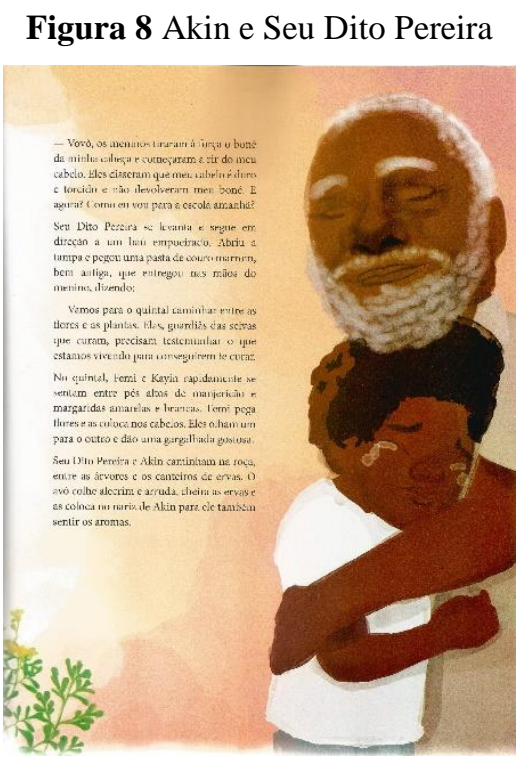

Fonte: Rodrigo Andrade, OLIVEIRA (2020, p. 23)

Seu Dito Pereira pega num baú, uma pasta de couro marrom, leva os netos para o quintal e todos caminham entre flores e plantas, e explica a eles que elas são guardiãs das seivas que curam, pensamento peculiar da cosmovisão africana: "O avô colhe alecrim e arruda, cheira as ervas e as coloca no nariz de Akin para ele também sentir os aromas. (OLIVEIRA, 2020, p. 23). Já na cozinha, Seu Dito faz um preparo no fogão a lenha, utilizando colher de pau, insere banha de porco e as ervas colhidas. Tal preparo, depois, será passado no cabelo de Akin.

Na pasta de couro marrom, há desenhos, dentre os quais do caçador do sonho, e fotos dos antepassados da família de Akin: todos são negros e possuem cabelo crespo.

- Filho, jamais reproduza os xingamentos que você aprende com seus colegas violentos, não é correto. O que você não conseguiu enxergar nas imagens é o orgulho que nós demonstramos ter de nós mesmos e do nosso cabelo crespo. Nosso cabelo é crespo, filho. Herdamos essa crespitude dos nossos antepassados, de rainhas e de reis, africanas e africanos. (OLIVEIRA, 2020, p. 25) 
Assim como descrito por Duarte (2008), o resgate de figuras negras heroicas e importantes ocorre, pois Seu Dito retoma os feitos históricos do povo africano escravizado no Brasil a fim de fortalecer a identidade do neto (figuras 9 e 10). Emicida, no Prefácio da obra em análise, diz que é preciso entrar em contato as imagens afirmativas e cita que, mexendo nos antigos discos de vinil do pai dele, encontrou cabelos crespos soltos, enormes e altivos.

Neste processo de afirmação, as cores claras e escuras da ilustração simbolizam a "cura" de Akin.

Figura 9 - Akin e as imagens dos antepassados

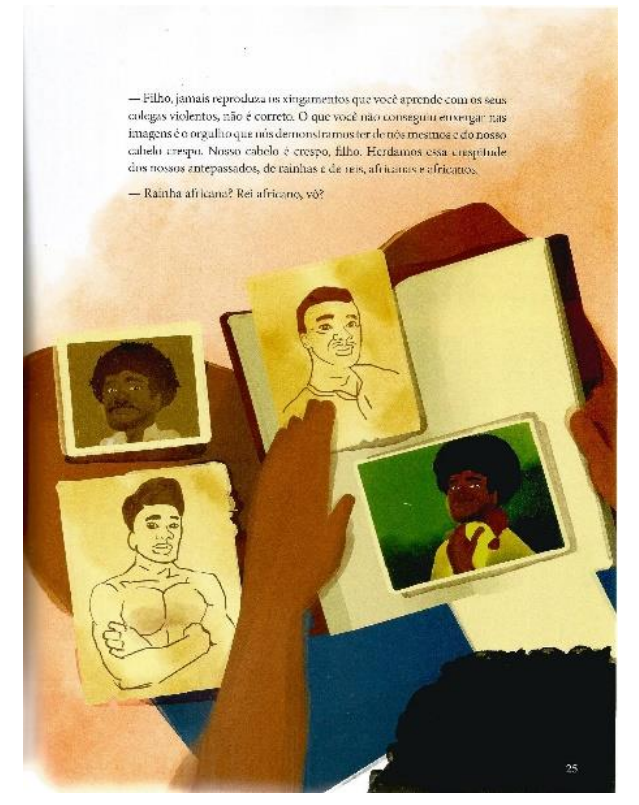

Fonte: Rodrigo Andrade, OLIVEIRA (2020, p. 25). 
Figura 10 - Akin e as imagens dos antepassados

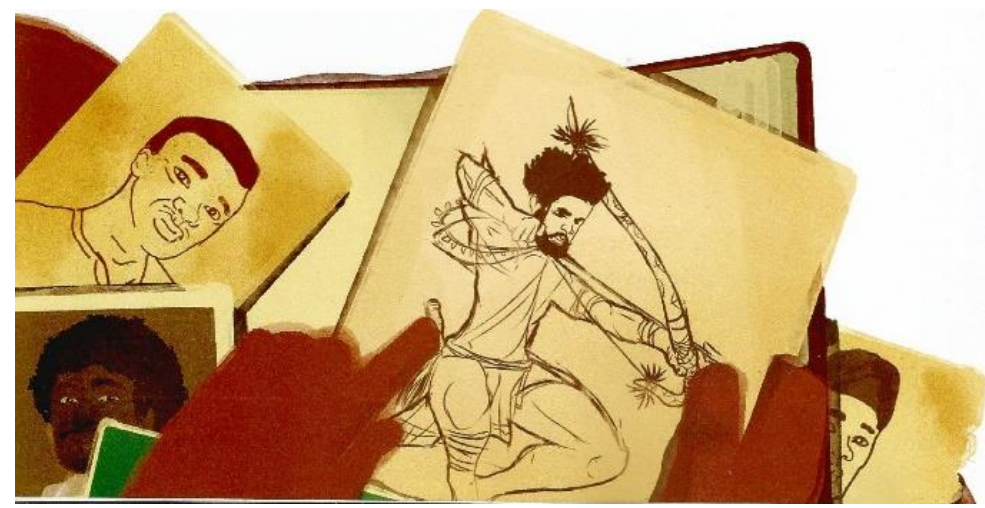

Fonte: Rodrigo Andrade, OLIVEIRA (2020, p. 26).

De acordo com Cabral (2019, p. 123), “O livro infantojuvenil é um conjunto de linguagens que se falam, que em sua singularidade e em conjunto podem modificar a leitura: é um corpo plural e complexo. Isso faz dela uma obra de arte singular e única”. (CABRAL, 2019, p. 123). A cura de Akin é reiterada com o tesouro africano: um garfo de marfim:

Seu Dito Pereira pegou o garfo das mãos de Akin e começou a pentear os cabelos crespos do neto. Os fios, envolvidos naquele hidratante, deslizavam brilhantes como fios de seda fabricados na hora pelo próprio bichinho. O Avô não poupou os fios nem tampouco o garfo: armou o mais que pôde os cabelos do neto. Seu Dito Pereira fez maior black power do mundo. (OLIVEIRA, 2020, p. 27).

Figura 11 - Akin se vê como Príncipe

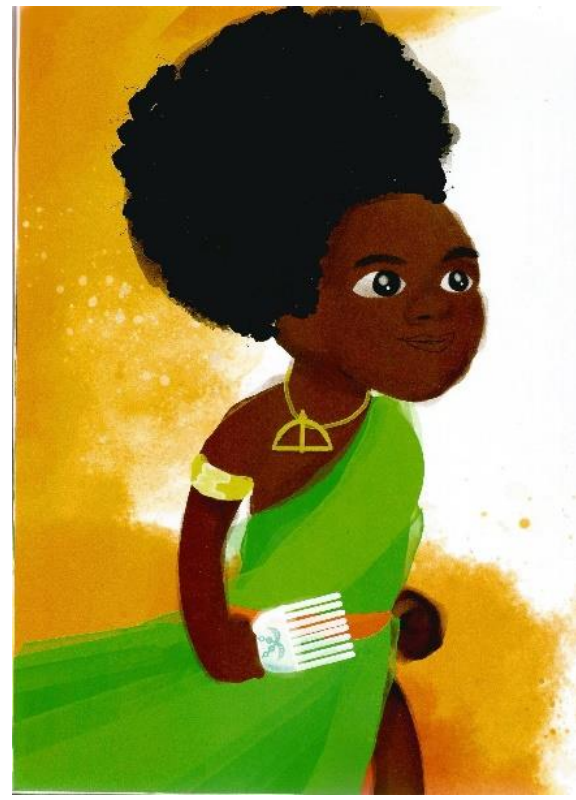

Fonte: Rodrigo Andrade, OLIVEIRA (2020, p. 28). 
Com a identidade negra em processo de afirmação, por meio da singularidade da palavra e da ilustração (CABRAL, 2019), Akin sente-se Príncipe africano (figura 11) e, diferente do reflexo do espelho em que se vê branco de cabelo lisos e olhos azuis, pisca os olhos e percebe-se:

[...] rodeado por crianças na volta de uma das muitas caçadas vividas e com o nobre de marfim nas mãos. Piscou de novo, chacoalhou a cabeça e, ao abrir os olhos, se viu como ele próprio: um belo menino negro, com um penteado símbolo de glória e poder. Encantado com a visão, sorri. (OLIVEIRA, 2020, p. 29)

Como os conflitos de Akin são solucionados por conta da identidade negra afirmada, as cores das ilustrações em cores claras já não mais indiciam problemas, racismo e preconceito étnico-racial. Seu Dito Pereira, juntamente com os três netos, resolve ir à Escola para contar a história da família para os alunos, postura que demonstra o cumprimento do artigo 205 da Constituição Federal e da Lei 10.639 de 2003, segundo a qual a educação, "direito de todos e dever do Estado e da família, será promovida e incentivada com a colaboração da sociedade, visando ao pleno desenvolvimento da pessoa, seu preparo para o exercício da cidadania e sua qualificação para o trabalho" (BRASIL, 1988). Ela altera a Lei no 9.394, de 20 de dezembro de 1996, que estabelece as diretrizes e bases da educação nacional, para incluir no currículo oficial da Rede de Ensino a obrigatoriedade da temática História e Cultura Afro-Brasileira, e dá outras providências (BRASIL, 2003).

A família de Akin, em conjunto com a instituição escolar, colabora, por meio do cultura afro-brasileira, para que a intolerância étnico-racial seja minimizada. Dos cabelos crespos chacoalhados dos netos, diante dos demais alunos e da equipe gestora, saem objetos, dentre os quais awalé (jogo matemático africano) e os "rostos conhecidos escritores, cantores e intelectuais e ativistas negros, como Tia Ciata, Emicida, Carolina Maria de Jesus, Machado de Assis, Carol Conka, Abdias do Nascimento..." (OLIVEIRA, 2020, p. 32) (figura 12). 
Figura 12 - Ativistas negros dos cabelos dos netos

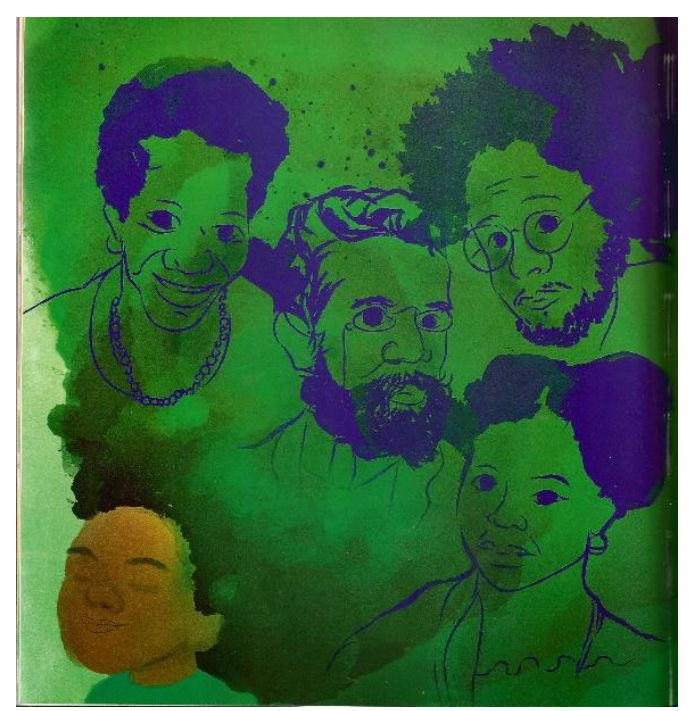

Fonte: Rodrigo Andrade, OLIVEIRA (2020, p. 32).

Diante desta conscientização oportunizada pelo Seu Dito Pereira, seus netos e pela equipe gestora da Escola Jacimba Gaba, Paulo e Marcos pedem desculpas a Akin e, posteriormente, convidam o menino para brincar:

- Desculpa, Akin, por tudo o que fizemos de ruim com você. É que nós não sabíamos da força e da grandeza dos africanos e afrodescendentes.

- Bora brincar? - sugeriu Marcos.

- Brincar de que? - quis saber Akin.

E foi Paulo quem respondeu:

- Akin será o grande guerreiro africano. (OLIVEIRA, 2020, p. 33)

Percebe-se que os mecanismos de aquisição de atitudes raciais descritas por Fazzi (2004) e o racismo estrutural sinalizado por Almeida (2020), presentes nas ações de Paulo e Marcos, foram repensados a partir de atitudes antirracistas e da conscientização proporcionada pela ação de Seu Dito e netos. 
Figuras 13 e 13.1 - Seu Dito Pereira e os netos

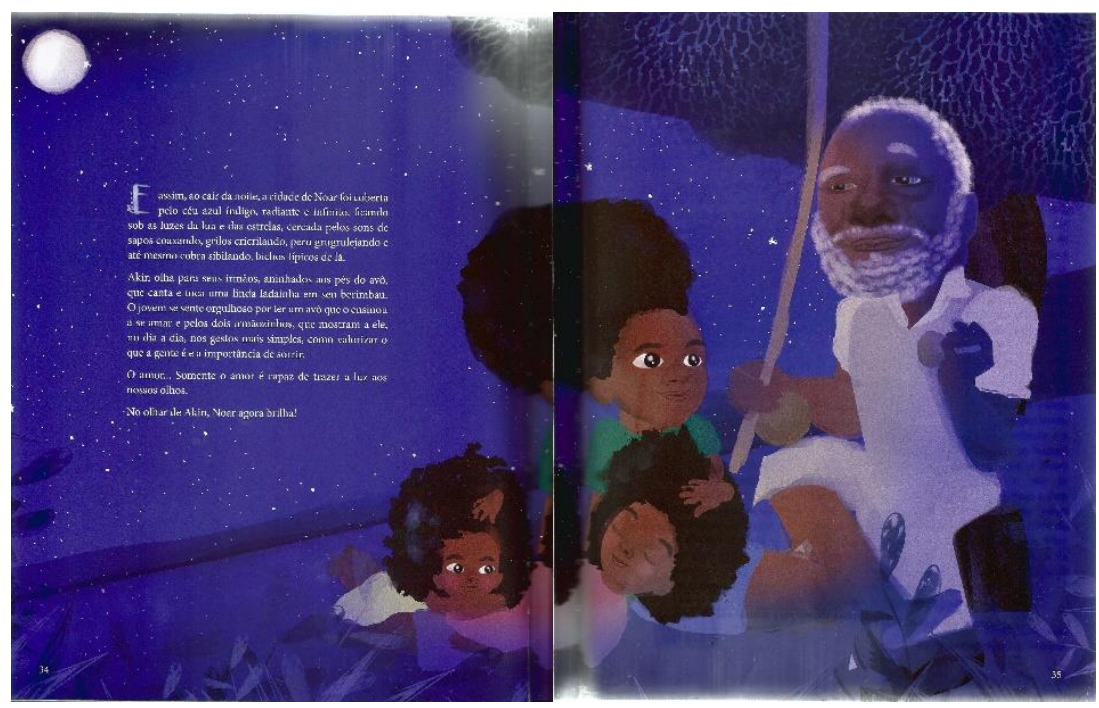

Fonte: Rodrigo Andrade, OLIVEIRA (2020, p. 34-35).

Seguidas das cores escuras em verde (figura 12), as finais (figuras 13 e 13.1) retomam a cor da noite, simbolizando a cor ancestral e a simbologia da noite africana. Reunidos, Akin e os irmãos ouvem a ladainha acompanhada de berimbau cantada por Seu Dito Pereira.

Por fim, a Literatura "kiusamiana", juntamente com a ilustração de Rodrigo Andrade, dá à obra a reflexão e a discussão necessárias sobre os corpos negros libertos do sofrimento causado em situações de conflitos pelo não entendimento e pela violentação (CRUZ-NETO; MINAYA, 1994) destes corpos por construções racistas, preconceituosas ao longo dos séculos.

A Literatura Negra do Encantamento, por ter o foco nas questões ancestrais e em fortalecer as identidades negras:

[...] é capaz de atingir as estruturas psíquicas mais profundas de jovens e crianças negras, provocando as costuras psíquicas necessárias para que suas identidades, fragmentadas pelas vivências racistas, sejam reconstruídas de forma saudável. Tal literatura depende da arte presente nas ilustrações que devem encantar as crianças e jovens negros para que se sintam orgulhosos do que veem e se reconheçam naquelas imagens. (OLIVEIRA, 2017, p. 12)

A literatura tem, desta forma, o poder de auxiliar em situações de conflitos relacionados aos problemas associados aos corpos negros, ao corpo social, às relações e 
às tensões interpessoais, leitores de diferentes etnias a se conscientizarem. Pereira (2016, p. 437), explica que a literatura para crianças e jovens, voltada para a temática afro-brasileira e africana, consiste num espaço privilegiado para a elaboração de um discurso afirmador da diferença, da multiculturalidade e de reescrita da ideia de nação que se choca com o ideário anterior de exaltação da miscigenação e de nação homogeneizada.

\section{CONSIDERAÇÕES FINAIS}

Coutinho (2019) tece contribuições pertinentes acerca da Teoria, da História e da Crítica Literária no Brasil. Segundo o pesquisador, em decorrência de um longo processo de colonização que ainda hoje perdura, mesmo que não mais das mesmas matrizes, do ponto de vista econômico e cultural, os intelectuais brasileiros e hispanoamericanos sempre tomaram ideias e instituições europeias como paradigmáticas e buscaram internalizar a visão de mundo desses povos.

Para o pesquisador, o ensino e a pesquisa da Literatura naqueles contextos voltaram-se, na maioria das vezes, aos modelos europeus. Contudo, com as transformações ocorridas na segunda metade do século XX, esses modelos foram postos em xeque, dando lugar a uma tensão entre os docentes e os pesquisadores que defendiam o estudo da literatura como expressão do espírito nacional e os que passaram a abordar a literatura como uma entre as muitas expressões da afirmação política de cada grupo que forma o mosaico étnico-cultural do continente.

Assim, as reflexões sobre o papel dos Estudos Literários hoje e suas implicações no ensino motivaram a refletir de que modo o texto escrito literário e a imagem da ilustração podem ser pensadas de forma crítica no que diz respeito ao processo de afirmação da identidade negra na obra $O$ Black Power de Akin.

Além disso, Coutinho (2019) destaca que os estudos da Antropologia, da História e da Sociologia precisam fazer parte da fundamentação crítica e da análise de textos, o que motivou a inserção destas áreas de conhecimento no presente artigo.

A organização da palavra literária e da ilustração, atreladas à simbologia africana e afro-brasileira, mostrou-se peculiar no processo de afirmação da identidade negra de Akin. Ao tomar conhecimento da ancestralidade e de seus valores, o 
protagonista teve a identidade fortalecida dentro (Seu Dito Pereira) e fora do espaço escolar (Gestão da escola) que, juntas, permitiram este percurso em Akin.

\section{Referências}

ALMEIDA, Jacqueline de; KIRCHOF, Edgard Roberto. Literatura Negra, Poesia e Combatividade: uma análise do poema 'Sou Negro', de Luiz silva, o Cuti. ANTARES: Letras e Humanidades, Caxias do Sul, v. 10, n. 21, set./dez. p. 55-69. 2018.

ALMEIDA, Sílvio Luiz de. Racismo estrutural. São Paulo: Jandaira, 2020.

ALVES, Miriam. Cadernos Negros (número 1): estado de alerta no fogo cruzado. Em: FIGUEIREDO, Maria do Carmo Lanna; FONSECA, Maria Nazareth Soares (org). Poéticas afro-brasileiras. Belo Horizonte: Mazza PUC Minas, 2002. P. 153-161.

AMORIM, Simone Silveira; MACHADO, Tatiane Trindade. O berimbau me deu o compasso: A capoeira e suas manifestações em Sergipe, no século XIX. Revista Brasileira de História da Educação. Maringá, volume 18, p. 2-21, 2018.

BENISTE, José. Dicionário yorubá-português. Rio de Janeiro: Bertrand Brasil, 2014.

BERND, Zilá. Introdução à literatura negra. São Paulo: Brasiliense, 1988.

BRASIL. Lei 10.639/2003. Brasília: Diário Oficial da União, Poder Executivo, 2003.

BRASIL. Lei $n^{\circ}$ 9.394, de 20 de dezembro de 1996. Estabelece as Diretrizes e Bases da Educação Nacional. Brasília: Senado Federal, 1996.

BRASIL. Constituição da República Federativa do Brasil. Brasília: Senado Federal, 1988.

CABRAL, Bianca Rodrigues. A voz da personagem criança e a ilustração: um jogo de silêncios. Revista Palimpsesto, n. 29, ano 18, 2019, p. 121-136.

CORTAZZO, Uruguay. Branquitude e crítica literária. Literafro. 2011. Disponível em: www.letras.ufmg.br/literafro/.../48-uruguay-cortazzo-branquitude-e-critica-literaria. Acesso em 10 de janeiro de 2021.

COUTINHO. Eduard de Faria. Palestra intitulada A reconfiguração de identidades e suas implicações nos estudos literários latino-americanos. Em: VII CONGRESSO NACIONAL DO PROGRAMA DE PÓS-GRADUAÇÃO EM LETRAS E XX SEMINÁRIO DE ESTUDOS LITERÁRIOS DA UNESP/IBILCE/SJRP, 2019.

CRUZ-NETO, Otávio; MINAYA, Maria Cecília de. Extermínio: violentação e banalização da vida. Caderno Saúde Pública. Rio de Janeiro, número 10, p. 199-212, 1994.

DALCASTAGNÈ, Regina. Por que precisamos de escritoras e escritores negros? In: 
SILVA, Cidinha da (Org.). Africanidades e relações raciais: insumos para políticas públicas na área do livro, leitura, literatura e bibliotecas no Brasil. Brasília: Fundação Cultural Palmares, 2014. p. 66-69.

DALCASTAGNÈ, Regina. Homem, branco, rico e heterossexual. Entrevista feita por Paula Santos pelo Boletim número 1619, ano 34 de 04 de agosto de 2008. Disponível em: https://www.ufmg.br/boletim/bol1619/5.shtml. Acesso em 10 de janeiro de 2021.

DEBUS, Eliane. A temática da cultura africana e afro-brasileira na literatura para crianças e jovens: lendo Joel Rufino dos Santos, Rogério Andrade Barbosa, Júlio Emílio Brás, Georgina Martins. Florianópolis: NUP/CED/UFSC, 2017.

DUARTE, Eduardo de Assis. Literatura afro-brasileira: um conceito em construção. Estudos de Literatura Brasileira Contemporânea, n. 31, p. 11-23, Brasília, jan.-jun. 2008.

FAZZI, Rita de Cássia. O drama racial de crianças brasileiras. Socialização entre pares e preconceito. Belo Horizonte: Autêntica, 2004.

FONSECA, Maria Nazareth Soares. Vozes em discordância na literatura afro-brasileira contemporânea. Em: FIGUEIREDO, Maria do Carmo Lanna; FONSECA, Maria Nazareth Soares (org). Poéticas afro-brasileiras. Belo Horizonte: Mazza PUC Minas, 2002, p. 191-220.

FORD, Clyde. O herói com rosto africano: mitos da África. Tradução de Carlos Mendes Rosa. São Paulo: Summus, 1999.

GOMES, Nilma Lino. Sem perder a raiz: corpo e cabelo como símbolos da identidade negra. Belo Horizonte: Autêntica, 2006.

GONÇALVES, Patrícia. 17 mulheres negras brasileiras que lutaram contra escravidão. Portal Geledés. Disponível em: https://www.geledes.org.br/17-mulheres-negrasbrasileiras-que-lutaram-contra-escravidao/. 2017. Acesso em 10 de janeiro de 2021.

MUNANGA, Kabengele. Prefácio. Em: GOMES, Nilma Lino. Sem perder a raiz: corpo e cabelo como símbolos da identidade negra. Belo Horizonte: Autêntica, 2006.

OLIVEIRA, Kiusam de. O Black Power de Akin. Ilustração de Rodrigo Luís de Andrade. São Paulo: Cultura, 2020.

OLIVEIRA, Kiusam de. Pedagogia da ancestralidade. SESC eonline. Disponível em: https://www.sescsp.org.br/online/artigo/13431_PEDAGOGIA+DA+ANCESTRALIDA DE. 2019. Acesso em 10 de janeiro de 2021.

OLIVEIRA, Kiusam de. A criança é capaz de reproduzir o racismo que vê. Entrevista concedida a Camilla Hoshino. Luneta. 2017. Disponível em: https://catraquinha.catracalivre.com.br/geral/defender/indicacao/entrevista-kiusamdeoliveira/. Acesso em 10 de janeiro de 2021. 
PEREIRA, Luena Nascimento. Literatura Negra Infanto-Juvenil: Discursos afrobrasileiros em construção. INTERSEÇÕES, Rio de Janeiro, v. 18 n. 2, p. 431-457, dez. 2016.

PORTER, Judith. Black child - the development of racial Attitudes. Massachussetts. Harvard University Press, 1973.

SILVA, Pedro Henrique Souza da. Africanidades e relações raciais: insumos para políticas públicas na área do livro, leitura, literatura e bibliotecas no Brasil. Literafro. Disponível em:

http://www.letras.ufmg.br/literafro/arquivos/resenhas/ensaio/CidinhadaSilvaAfricanidad eserelacoesraciais.pdf. 2014. Acesso em 10 de janeiro de 2021.

Recebido em: 03/02/2021 Aceito em: 02/04/2021 